\title{
Influence of Organisational Culture on Employee Commitment: Evidence from Environmental Protection Agency in Ghana.
}

\author{
Hannah E. A. Acquah ${ }^{1}$, Noble Amoako Sarkodie ${ }^{2}$, Enoch Baffoe,${ }^{3}$ Adams Lennox, ${ }^{4}$ Djanie Benjamin \\ Nii Amon $^{5}$ and Joseph Nunoo ${ }^{6}$ \\ ${ }^{1}$ Department of Business Administration (Senior Member) University of Professional Studies, Accra-Ghana. \\ ${ }^{2}$ Department of Hospitality and Tourism. Sunyani Technical University. \\ 3, 4, 5 Department of Business Administration, (Junior staffs) University of Professional Studies, Accra. \\ 1Correspondence:esiaab71@yahoo.com
}

\begin{abstract}
This study assesses the influence of culture on employee commitment at Environmental Protection Agency in Accra. The study adopted quantitative method using descriptive survey. One hundred and twenty-six (126) employees were selected using convenience sampling technique. The primary data was gathered using questionnaire and validated through Cronbach Alpha. In analysing the data gathered, descriptive as well as inferential statistics were employed. It was observed from the outcome that, the four culture dimensions used by the researchers all existed at the organisation. Further, training and development; reward and recognition; team work and organisational communication all showed significant relationship with employee commitment at the organisation. Thus, there was a positive effect between cultural practices in the organisation and employee commitment. Management must there ensure the fostering of strong culture to help retained committed staff which eventually reduce high turnover.
\end{abstract}

Keywords: Corporate culture, organisational commitment, environmental protection agency.

Citation: Acquah, H. E. A., Sarkodie, N. A., Baffoe, E., Lennox, A., Amon, D. B. N. and Nunoo, J. Influence of Organisational Culture on Employee Commitment: Evidence from Environmental Protection Agency in Ghana, 2020; 5(3): 45-57.

Received: May 28, 2020

Accepted: September 30, 2020 


\subsection{Introduction}

Global competition and survivals of organisations have led to the search into organisation effectiveness by numerous researchers. Quite a number of such works in the literature debated on variables that are critical to the effective functioning of organisations. Central to these variables is organisational culture perhaps because of its uniqueness to depict the way organisations behave. Organisational culture has been an important theme in management and business research over the past few times due to its potential to affect a range of organisationally and individually desired outcomes such as commitment, loyalty, turnover intent, and satisfactionll (Chow et al., 2001). While some researchers argued that organisational culture could exert influence substantially in the areas such as performance and commitment of organisations; Deal \& Kennedy (1982); Peters \& Waterman (1982) and others confirmed that corporate culture is able to influence the thoughts, feelings, interactions and organisational performance (Yusof \& Ali, 2000; Saeed \&Hassan, 2000). But to Olu (2009), organizational culture and its relationship with employees' commitment has become the focus of research in fields such as strategic management, organizational behaviour and industrial organisations. Olu further argued that many researchers agree on the verifiable truth that there is no agreement on the exact nature of the relationship existing among commitment of employees and culture in an organisation even though there are numerous studies conducted on the said topic in the advanced countries. Fard, Rajabazedah, \& Hasari, (2010) argued in their work that a relationship existed between commitment and employee performance in the public sector organisations and found that organisational commitment can be caused by a variety of demographic and situational factors. The factors proposed by the researchers' included but not limited to the organisation's size, structure, and managerial characteristics indicating that staffs of organisations become committed to organisations in which they work through diverse motivators. Elaborating further, Malik, Nawab, Naeem \& Danish (2010) contend that personal characteristics affect employee commitment. The attributes consist of the employees' ability to identify with the organisations mission, level of confidence and internal or external motivation. Whilst other researchers have argued that most of the studies in the area of organisational commitment showed that employees working in private organisations are more likely to be committed than public sector employees (Goulet and Frank, 2002; Cho and Lee, 2001).

Civil servants in Ghana, however, according to Abdul-Nasiru, Mensah, Amposah \& Simpeh (2014) are thought often as idling around, working lotto numbers and perhaps newspapers reading during times that employees are likely to be occupied towards the achievement of goals for which they were employed. Is this really the case at Environmental Protection Agency, a public sector organisation in Ghana? This study reveals it through empirical evidence.

Specifically, the research seeks response to the question; does the corporate culture: training and development; reward and recognition; teamwork and organisational communication have any influence on employee commitment at Environmental Protection Agency in Ghana? The study is guided by the following hypotheses:

- H1: there is a significant relationship between training and development and Employee Commitment.

- H2: There is a significant relationship between Reward and Recognition and Employee Commitment.

- H3: There is a significant relationship between teamwork and Employee Commitment

- H4: There is a significant relationship between organisational communication and Employee Commitment.

1. The study would serve as a reference material for researchers engaged in similar studies.

2. This study has beef up literature on the culture of organisations and the effect on employee commitment at a public sector organisation.

3. It is hoped that the findings will help both public and private organisations' management to undertake a self-check of the various organisational culture types that positively affects employee commitment so that action could be taken to minimise any high turnover. 
4. The study facilitates individual researchers to identify gaps in the current study and carry out research in those areas.

5. The study beefs up to knowledge in organisational culture types and practices especially in a public sector organisation and their implications to employee commitment.

6. It is hoped that the findings will contribute to the discussion on organisational culture types on staff commitment at private sector organisations in future research.

\subsection{Literature Review}

\subsection{Organisational culture}

Organisational culture is defined otherwise by many experts as indicated by Anderson \& West (1998). Perhaps the most commonly known explanation is way of doing things. Martins \& Martins (2003) in their work propose that culture of an organisation is seen as a system of shared meaning held by members, distinguishing the organisation from other organisations. Organisations therefore have very definite "culture" and culture forms an integral part of the general functioning of the organisation from literature. Kumawu \& Kraus (2007) are of the view that organisational culture is "the rules of getting along in the organisation". Basically, an organisational culture expresses the persona of the organisation. Culture comprises the traditions, values, norms and tangible signs of the members as well as their behaviours within an organisation. Sooner or later, members of the organisation come to the realization of the precise culture of the organisation. Though culture is very difficult to express distinctly, individuals in the organisation knows it when they sense it. Sometimes, one can express the culture of an organisation by simply observing the arrangement of furniture, and what staffs wear. Organisational culture can also be considered as a system with the inputs comprising feedback from society, laws and values. The outputs or effects of culture are organisational behaviours, technologies, strategies, image, and services among others.

Harrison (1993), cited by Acquah, Seshie \& Zogbator (2015) reasoned that what usually distinguishes one organisation from the other are; work styles, values, beliefs, as well as relationships. Consequently, organisations have specific qualities with a precise climate or feel and usually shown through four dimensions as: power, role, achievement and support. Researchers including Meyer \& Allen (1991) and Ricardo \& Jolly (1997) among others had earlier identified the following as the most practices of dimensions of organizational culture: training/development, communication, rewards/recognition, risk taking for creativity and innovation, effective decision making, proactive learning, team work, and fairness and consistency. However, Lau \& Idris (2001), argued that the dimensions of culture identified to have great effect on employees' behavior and commitment in organisations included; communication, teamwork, training/development and reward/recognition. These four dimensions of culture types have been adopted for this study and explained as follows.

2.2 Training and Development (T\&D)

Poh (2001) defined training and development as "the procedure of providing employees with specific expertise and to eliminate shortcomings in their work" where as to Cherrington (1995), a successful training and education program most of the times make employees' loyal as well as the creation of a more favourable employee attitudes helping in the advancement and personal development of the employees.

In a similar study, Soltani \& Liao (2010) write about training as "one of the several human resource flows which altogether lead to achieving the 'four Cs' of HR outcomes: commitment, congruence, competence and cost effectiveness". This means that training as a tool assists organisation to create better and more productive work since a good training program can create high commitment and reduce turnover of staff. Some of the advantages stressed by Jumba (2016) are that, an organisation with a well-trained staff may enjoy increased productivity, reduced employee turnover, increased efficiency resulting in financial gains and decreased need for supervision. Therefore, training and development policy play an importance role in human resource management and contribute to improved strategic integration, employee commitment, flexibility and quality. Human resource management outcomes from 
the literature lead to following; high job performance, high problem solving activity, high cost effectiveness and low turnover, reduced absences and fewer grievances etc. The argument from Soltani \& Liao (2010) and others from the literature support the hypothesis that; training and development and employee commitment are related significantly. 2.3 Reward and Recognition (R\&R)

Juran \& Gryna (1993) defined reward and recognition as "benefits such as increased salary, bonuses, and promotion, which are conferred as public acknowledgement of superior performance with respect to goals". Accordingly, Chew and Chan cited in Ghina (2012) debated that remuneration and recognition positively predicted organisational commitment and intention to stay. Additionally, Herzberg's cited in Jumba (2016) deliberating on the hygiene/motivator theory reasoned that one of the four motivators, when present contributes to employee commitment is recognition. Reward and recognition activities are valued by employees and therefore provide motivation or incentives. If executed appropriately, these activities can, to a certain degree improve employees' productivity. From the works of Chew and Chan cited in Ghina (2012) and other works from the literature, it is possible to hypothesized that; Reward and Recognition practices can influence Employee Commitment.

2.4 Team Work $(T W)$

Teamwork and teams as a concept is becoming cumulative vital to employees' commitment and their productivity in the modern business arena. Team work from the literature could also be explained as the collaborative effort of a group to attain a common goal or to complete a task in the most effective and efficient way. A team may be viewed as a group of individuals who work interdependently to solve problems or accomplish tasks (Gibson \& Kirkman, 1999; Manz \& Sims, 1993 in Ghina, 2012). Teamwork as debated by Karia \& Ahmad (2000) enables the affiliate needs within the workplace to gather and directly associated to organisational commitment. Team working makes possible the affiliation needs within the organisation and is positively associated to organisational commitment (Karia \& Asaari, 2006). It is important for managers to build teams to enable them attain their goals. This is the reason why team building has been used in Japanese super markets where managers ultimately depend on the ability of their members to work together to accomplish competitive supremacy. Management thus employ the team approach to link and align available resources towards accomplishment of the goals of the organisation and equally facilitate the group harmony. (Dwivedi, 2006).

2.5 Organisational Communication (OC)

Organisational communication refers to the process where individuals and groups transact in a variety of ways and within different areas with the aim of carrying out organisational goals (Smidts et al., 2001, as cited in Jumba, 2013). It is an effective tool which organisations can use to connect the existing culture in the organisation to its employees towards attainment of organisational goals. A study conducted by Goris et al. as cited in Ghina (2012) argued that communication is central for the improvement of employees' commitment and for positive outcomes. The manner in which the goals of the organisation and employees' role in the advancement of goals are communicated to employees' strongly affects organisational commitment and productivity. (Anderson \& Martin cited in Jumba, 2013). In a similar study, Saiyadin cited by Naicker (2008) opines that culture does the following in organisations; "culture supplements rational management" as well as the "creation of work culture is a time-consuming process. Culture of organisations thus cannot suddenly change the behaviour of people within an organisation. Culture communicates to people through symbols, values, physical settings, and language, and thereby supplements the rational management tools such as technology and structure. Further, culture facilitates induction and socialization of which induction is a process through which new entrants to an organisation are socialised and indoctrinated in the expectations of the organisation, its cultural norms and undefined conduct. The new employee imbibes the culture practiced within the organisation and may perhaps contribute to changing the employee's attitudes and beliefs to achieving an internalized commitment to the organisation.

\subsection{Employee Commitment}

Newstrom and Davies cited in Naicker, (2008) explains employee commitment as the degree to which an employee identifies with the organisation and wants to continue actively participating in it. It was observed from the literature that employee commitment measures the willingness of employees to remain with a business/firm in the future 
perhaps like a magnetic force attracting one metallic object to another. The commitment of employees thus reflects the belief employees have in both the mission and goals of the organisation likewise the willingness to apply effort in the achievement and intentions to continuously work with the firm.

Dixit and Bhati (2012) postulate that in today's competitive world every organisation is facing new challenges regarding sustained productivity and creating committed workforce. Nowadays, perhaps there is no organisation performing at its peak unless employees are committed to the objectives of the organisations. As a result, it is important to understand the concept of commitment and its feasible outcome. Hakim (2015) defines organisational commitment as "the desire and the willingness of employees to remain in the organisation and devote themselves to the success of the organisation". Amernic and Aranya in Bizuneh (2016) write that two major theoretical approaches have been employed in the literature on organisational commitment: the exchange approach and the investment approach. These researchers summarized previous researchers' explanation regarding these two approaches as follows;

First, the exchange theory discusses that individual's organisational commitment depends on his or her perceived balance of reward utilities over input utilities. This approach emphasizes the exchange relation between individuals and organisations. Thus, the more favorable exchange from the participant's viewpoint, the greater the employee's commitment to the organisation.

Secondly, the investment approach focuses on the time element; the longer a person has been with an organisation, the more that person wants to stay. This encompasses tenure and pension benefits or social involvements, which is the interaction and identification with other members of the organisation.

\subsection{Organisational Culture and Commitment works}

Boon \& Arumugam (2006) conducted a study on the topic "the influence of corporate culture on organisational commitment: case study of semiconductor organisations in Malaysia". The study was aimed at investigating the "influence of four dimensions of corporate culture (teamwork, communication, reward and recognition, and training and development) on employees' organisational commitment within six major Malaysian semi-conductor packaging organisations". Notwithstanding extensive research on corporate culture, not much has been done empirically in this area of study. Hierarchical regression analysis was used in testing the research hypothesis. The outcome of the study revealed that "communication, training and development, reward and recognition, and teamwork are positively associated with employees' commitment". Additionally, "communication was perceived as a dominant corporate culture dimension" and also associated with significant improvements in employees' organisational commitment. The study did contribute to better understand the "influence of corporate culture on organisational commitment among employees within the context of Malaysian semiconductor sector." The concentration was however limited to only the Malaysian semiconductor sector therefore; the results cannot be generalized to the Ghanaian Public sector employees, taking EPA employees into consideration.

Ghina (2012) examined the corporate culture influence on employees' organisational commitment at a Malaysian Listed Company. Using questionnaire survey, the study examined dimensions of the influence of four corporate culture as; teamwork; communication; reward and recognition; training and development on employees' commitment towards the organisation. A hundred and ninety (190) individuals from a Malaysian listed company did participate in the survey. The study also employed hierarchical regression in the hypothesis testing just as Boon \& Arumugam (2006) used for their research. The outcome showed that all the dimensions of corporate culture selected for the study motivate employees to be committed to their respective organisations. The findings disclosed that an organisation needs to be aware of the importance of these dimensions to providing a favourable working environment to its employees in attaining full commitment for organisationl success.

Majeed et al. (2012) researched on the topic "the influence of corporate culture on organisational commitment of Pakistani Banks an empirical study". The study had as its purpose to examine the influence of four dimensions of corporate culture on employees' organisational commitment at the Pakistan Banking Sector. The study targeted a population of 600 and the sample size was 234 , however the respondents were selected randomly. Data was collected through personally administered questionnaires filled from different public and private banks. Out of the 234 
distributed questionnaires, 189 were filled. It was revealed from the analysis that all "four dimensions of Corporate Culture are positively associated with employees' commitment" to the organisation, however, communication was recognized as the dominant culture. The study concentrated on the banking industry in Pakistan and that the results cannot be generalized in the African Diaspora, taking Ghana into consideration.

Lauture et al. (2012), conducted a study on the "impact of Culture on the Organisational Commitment of PublicSector employees in Haiti". The aim was to show the relationship between cultural attributes and their effects on Employee commitment in the public sector. A total of 150 questionnaires were distributed to various levels of employees in the Haitian Ministry of Justice and Public Security. One hundred and four (104) employees responded out of 150 generating an overall response rate of $69 \%$. It was concluded that positve perception of organisational culture increase employees commitment. Thus top managers should be able to forestall the priorities of the employees and implement an organisational culture that predominantly focuses on factors such as skills development and training and staff development. These factors contribute strongly to build the employee's affective commitment. This study even hough based on the public sector, applied to only employees at Haiti.

Shoaib, Zainab, Maqsood \& Sana, (2013), studied "impact of organisational culture on organisational commitment: A comparative study of public and private organisations". The study purposed to investigate the commitment levels of the employees' effect on culture by considering the demographic variables of respondents. The survey constituted 371 respondents from the banking sector and results showed that clan culture was preferred by the respondents perhaps of the simple reason that its operation being more like families, places value on cohesion and humane working environment, group commitment and loyalty. Further, it showed that clan culture, compared to the other types of culture had the most significant relationship to the three commitment dimensions employed in the study. Likewise, using the demographic variable of gender, it was found that females were more motivated towards affective commitment within the organisation as compared to male counterparts. Additionally, no difference existed for the continuance commitment although males as compared to females were highly inclined towards normative commitment.

Mba (2013) examined “organisational culture and employees' commitment in Bayelsa State civil service." The study population involved all the 20,000 civil servants within the 20 ministries and parastatals in the State of Bayelsa. By the usage of judgmental sampling, a sample size of 200 was used. The researcher employed descriptive research design using 200 randomly selected respondents from the population. Primary data collection precisely questionnaire administration was employed while data collected were analysed by use of both descriptive and inferential statistics. Results from the analysis showed significant relationship existing between culture and employees 'commitment though significant differences were observed in the commitment of employees of different sex, ages and length of service in the Bayelsa State civil service. It was therefore recommended by Mba (2013) among others that: "encouragement of work teams among employees, training and re-training of employees, improvement in the reward system, improvement of internal communication channels and employees participation in decision making."

Researchers Ramdhani, Ramdhani, \& Ainisyifa, (2017) analysis on some past works developed and used concepts to clarify how corporate culture dimensions effected commitment of employees. These researchers employed model analysis established on previous research works from the literature with the methodology based on the hypotheses. It showed from the analysis that corporate culture involving communication, teamwork, reward-recognition and training and developed could be developed from employee commitment to organisation. Additionally, the researchers observed that, by the enhancement of employee commitment through the continual generation of application of corporate culture, competence, effectivity and productivity of organisations could be sustained. Finally, Ramdhani, Ramdhani, \& Ainisyifa, (2017) reasoned that "concept of employee commitment to organization is designated with causal relationship toward corporate culture which is embedded into the dimension of communication, teamwork, reward- recognition and training development."

Al-Shurafat \& Abdul Halim (2018) reviewed published works from 2012-2017 on organisational culture and organisational commitment. More than half of the works reviewed indicated "strong significant interactions" existing between "organisational culture and organisational commitment" while there were few works showing weak 
association between culture and commitment with some equally showing no association among the variables. The researchers debated that the differences in methodology, different countries where the works were conducted as well as the differences in the respondents and observations taken for the studies perhaps might have resulted in the controversies of outcomes.

The literature reviewed indicated that organisational culture dimensions significantly affect employees' commitment. The present study thus seeks to explore the connection between organisational culture dimensions and employees' commitment if any specifically at the Environmental Protection Agency, Accra in Ghana.

\subsection{Methodology}

\subsection{Research Design}

A descriptive survey design was used by the researchers in this study. The significance of descriptive survey designs is that descriptive surveys are useful in describing the characteristics of a large population and with this broad capability, guarantee a more accurate sample to gather targeted results in which to draw conclusions and make important decisions. Hence, the study used survey since the employees are at their work place and easy to have access with them.

\subsection{Study Population}

The population for this research consists of employees of Environmental Protection Agency in Accra. The importance of the employees' opinion and voice cannot be underestimated and therefore were used as respondents in the study to capture their thoughts regarding influence of training and development on employees' commitment, influence of reward and recognition on employee commitment, effect of teamwork on employees' commitment and effect of organisational communication on employee commitment.

\subsection{Sample and Sampling Technique}

Convenience sampling was used to select all the employees who the researchers comes in contact with during the time of the data collection and are willing to provide the needed data are used. This gave the researchers opportunity to explain the purpose and importance of the research to respondents.

\subsection{Research Instrument}

In this study, closed-ended questionnaire was designed on a five- point Likert scales ranging from Strongly Disagree, Disagree, Neutral, Agree and Strongly Agree based mainly on the review of literature. The researchers employed closed ended questions since it did not require too much critical thinking to select the right responses. The Questionnaires was divided into two sections. Section A consisted of demographic profiles of respondents (age, gender, marital status, religion, educational background and length of service), whiles section B includes 21 statements constructed to collect information of organisational culture from the respondents and 8 statements to gather information on employee commitment. Finally, self-administered questionnaires were delivered to the selected respondents at their various work places to be filled by themselves.

3.5 Reliability and Validity

To achieve reliability, data was tested using a reliability test called Cronbach Alpha. 35 questions from both the dependent and independent variables were tested. The value of the Cronbach alpha for the study was 0.859 (85.9\%) meaning the overall reliability of data is acceptable. 
3.6 Data Analysis

After the collection of the questionnaires, the responses were edited and coded. This was done to ensure consistency and uniformity in the processing of the data. The data was analysed using computer software, Statistical Package for Service Solution (SPSS v. 20). After which Pearson's Correlation was used to analysis influence of training and development on employees' commitment, reward and recognition on employee commitment, effect of teamwork on employees' commitment and effect of organisational communication on employee commitment.

3.7 Ethical consideration

A letter was sent to head of Human Resource of Environmental Protection Agency in Accra to seek approval to allow employees to participate in the study. After, approval had been granted, the respondents who were willing to partake in the exercise were given the questionnaires to answer.

\subsection{Results}

\subsection{Pearson's Correlation Analysis}

Table 1

\begin{tabular}{llll}
\hline \hline \multicolumn{2}{c}{ Influence of Training and Development on Employees Commitment } & \\
\hline & & $\begin{array}{c}\text { Training and } \\
\text { Development }\end{array}$ & $\begin{array}{l}\text { Employee } \\
\text { Commitment }\end{array}$ \\
\hline \multirow{3}{*}{ Training and Development } & Pearson Correlation & 1 & $.499^{* *}$ \\
& Sig. (2-tailed) & & .000 \\
& $\mathrm{~N}$ & 126 & 126 \\
& Pearson Correlation & $.499^{* *}$ & 1 \\
Employee Commitment & Sig. (2-tailed) & .000 & \\
& $\mathrm{~N}$ & 126 & 126 \\
\hline \hline
\end{tabular}

**. Correlation is significant at the 0.01 level (2-tailed).

Source: Field work March, 2017

Table 2

\begin{tabular}{llll}
\hline Influence of Reward and Recognition on Employee Commitment & \\
\hline & & $\begin{array}{l}\text { Employee } \\
\text { Commitment }\end{array}$ & $\begin{array}{l}\text { Reward } \\
\text { Recognition }\end{array}$ \\
\hline \multirow{2}{*}{ Employee Commitment } & Pearson Correlation & 1 & $.581^{* *}$ \\
& Sig. (2-tailed) & .000 \\
& $\mathrm{~N}$ & 126 & 126 \\
Reward and Recognition & Pearson Correlation & $.581^{* *}$ & 1 \\
& Sig. (2-tailed) & .000 & 126 \\
\hline \hline
\end{tabular}

**. Correlation is significant at the 0.01 level (2-tailed).

Source: Field work March, 2017 
Table 3

\begin{tabular}{llll}
\hline \hline & Effect of Teamwork on Employees Commitment & \\
\hline & & $\begin{array}{l}\text { Employee } \\
\text { Commitment }\end{array}$ & Teamwork \\
\hline \multirow{3}{*}{ Employee Commitment } & Pearson Correlation & 1 & $.435^{* *}$ \\
& Sig. (2-tailed) & & .000 \\
& $\mathrm{~N}$ & 126 & 126 \\
Teamwork & Pearson Correlation & $.435^{* *}$ & 1 \\
& Sig. (2-tailed) & .000 & 126 \\
\hline \hline
\end{tabular}

**. Correlation is significant at the 0.01 level (2-tailed).

Source: Field work March, 2017

Table 4

Effect of Organisational Communication on Employee Commitment

\begin{tabular}{llll}
\hline & & $\begin{array}{l}\text { Employee } \\
\text { Commitment }\end{array}$ & $\begin{array}{c}\text { Organisational } \\
\text { Communication }\end{array}$ \\
\hline & Pearson Correlation & 1 & $.225^{*}$ \\
Employee Commitment & Sig. (2-tailed) & .011 \\
& $\mathrm{~N}$ & 126 & 126 \\
Organisational Communication & Sig. (2-tailed) & $.225^{*}$ & 1 \\
& $\mathrm{~N}$ & .011 & 126 \\
\hline \hline
\end{tabular}

*. Correlation is significant at the 0.05 level (2-tailed)

Source: Field work March, 2017

\subsection{Discussions and Implications}

The first objective of the study is to examine whether Training and Development Influence Employees' Commitment at Environmental Protection Agency (EPA). From table1, H1 is accepted in that there is a significant relationship between the respondents' level of Training and Development and Employee commitment at EPA because the sig. 2-tailed level is .000 and the relationship is positive $49.9 \%$. This implies that as the variable (Training and Development) increases, so will the dependent variable (employee commitment) and vice-versa. This outcome supports the works conducted by Ghina, (2012) and Majeed et al. (2012) that Training and Development as a culture dimension is positively related to employees' commitment. In an earlier study, Benson (2006) found that generally employees perceive skills development and training opportunities by the organisation as incentives thereby making the current work more attractive. Deducing from Benson (2006) works, training can be said to reduce staff turnover. 
Further, the study from Barlett (2001) showed that the variables related to training are highly associated to organisational commitment. These arguments support the objective that training and development as a corporate culture variable influences employee commitment.

The results in table 2 showed the existence of a significant relationship between Reward and Recognition and Employee commitment at EPA and $\mathrm{H} 2$ is accepted because the sig. 2-tailed level is .000 and the relationship is a positive $58.1 \%$. This suggests that as the level of Reward and Recognition of employees at EPA increases, their Commitment level also increases and so is the reverse. This supports the works of Boon and Arumugam (2006) and Majeed et al. (2012) which revealed that reward and recognition positively associated with employees' commitment respectively. Further, in their work, Locke \& Latham (1990) empirically showed that rewards positively influence Employee commitment in achieving their goals at work. The findings of these studies prove that there is indeed a positive link between Reward and Recognition and Employees Commitment.

The third hypothesis sought to establish whether teamwork practices at EPA can influence Employee Commitment. From table 3, it could be seen that the value of the Pearson's correlation coefficient for Teamwork ratings and Employee commitment ratings is $43.5 \%$ which implies that there exists a positive relationship between Teamwork and Employee commitment at EPA at a significance level of 0.000. This suggests that as the level of Teamwork maintained in the organisation (EPA) increases, Employee commitment improves. The study findings support some works in the literature. For example, Park et al. (2005); Boon \& Arumugum (2006); Ghina (2012) and Majeed et al. (2012) unravel that that there is a statistically significant relationship at 0.05 between teamwork and Employee Commitment.

The fourth hypothesis sought to assess whether organisational communication can influence employees' commitment at EPA. Table 4 shows a statistically significant relationship between organisational communication and employee commitment at a significant level of 0.011 . The value of the Pearson's correlation coefficient for organisational communication ratings and employee commitment ratings is $0.225(22.5 \%)$, suggesting that as the level of organisational communications in the organisation (EPA) increases, the commitment level of employees' commitment also increases. This discovery confirms the works by Boon \& Arumugam, (2006); Ghina (2012); Majeed et al, (2012) and Lauture, Amewokunu, Sherrie, \& Lawson-Body, (2012) showed a positive relationship between organisational communication and Employee Commitment respectively.

\subsection{Conclusions}

Organisational culture dimension is perceived by the employees of Environmental Protection Agency (EPA) as having a positive relation to their commitment, of which reward and recognition is the dominant organisational culture dimensions in the organisation. The employees perceive also that there exist four cultural dimensions in the organisation, which is Training and Development, Reward and Recognition, Teamwork, organisational Communication in the organisation. This means that management of Environmental Protection Agency has to restructure the organisational culture dimensions that is prevailing in the organisation to be consistent to the needs of their workers, such as training and development needs, reward and recognition needs, teamwork, communication and remove all hurdles that demotivate employees and lower their commitment level in the organisation. Employee performance thus would be enhanced and hence increase their level of commitment in the organisation and their aim to stay in the organisation. The findings of the study further revealed that indeed organisational culture has effect on employee commitment at Environmental Protection Agency.

This study has beef up literature on the study of culture in organisations and its effect on employee commitment at a public sector organisation. It is hoped that the findings will offer some guide to both public and private organisations' management to undertake a self-check of the various organisational culture types that positively affects employee commitment. This action when done, could foster strong culture in the organisation and eventually minimise any high turnover. 


\section{References}

Acquah, H. E., Seshie, P. O., \& Zogbator, B. E. (2015). an assessment of the impact of Organisational Culture on performance from faculty perspective in non-faith based private university colleges in Ghana. International Journal of Innovation and Scientific Research, 372-379.

Abdul , N., Mensah , R., Tawiah, K. A., Simpeh, K. N., \& Kumasey, A. S. (2014). Organisational Coommitment in the Public Service of Ghana: an Emperical Studies. Developing Country Studies, IV(1).

Al-Shurafat, M. S. \& Halim, B. B. A. (2018). A Review of Organisational Culture and

Organizational Commitment. Journal of Business and Management. Volume 20, Issue 3.

Amernic, J. H., \& Aranya, N. (1983). Organisational commitment: Testing two theories. Relations industrielles/Industrial Relations, 319-343.

Boon, K. O., \& Arumugam, V. (2006). The Influence of Corporate Culture on Organisational Commitment:A case Study of Semiconductor Organisations in Malaysia. Sunway Academic Journal, 99-115.

Cherrington, D. J. (1995). The management of buman resources. Englewood Cliff: NJ: Prentice-Hall.

Chew, j., \& Chan, C. C. (2008). Human Resources Practices, Organisational Commitment and Intention to Stay. International Journal of Manpower, 513.

Cho , K. M., \& Lee, S. H. (2001). "Another Look at Public-Private Distinction and Organisational commitment. International Journal of Organisational Analysis, 84-102.

Chow, C.W, Harrison, G.L, McKinnon, J.L and Wu, A. (2001). Organisational culture:

Association with affective commitment, job satisfaction, propensity to remain and information sharing in

Taiwan. International Journal of Business Studies, 11(1).25

Coffey, R.E., Cook, C.W. \&Hunsaker, P.L.(1994). Management and Organisational

Behavior. Irwin, Burr Ridge, IL.

Dayal, I., \& Saiyadin, M. S. (2003). Cross-Cultural Validation of Motivation-Hygiene Theory. JSTOR Business \& Economics, 171-183.

Dixit, V., \& Bhati, M. (2012). A study about Employee commitment and its impact on sustained productivity in Indian auto-component industry. European Journal of Business and Social Sciences,

$34-51$

Dwivedi, O. P., \& Khator, R. (2006). Sustaining development: the road from Stockholm to Johannesburg. public administration and public policy-new york, 118, 113.

Fard, H.D., Rajabazedah, A., Hasari, A. (2010). Organisational Trust in Public Sector: Explaining the Role of Managers"e Managerial Competency. European Journal of Economics, Finance \& Administrative Sciences, Vol. 25, p. 29-43.

Ghina, A. (2012). The Influence of Corporate Culture on Organisational Commitment;Case Study of Civil Government Organisations in Indonesia. International Journal, 01, 156-170.

Goulet, L. R., \& Frank, M. L. (2002). Organisational Commitment across Three Sectors: Public, Non-profit, and For-profit. Public Personnel Management, 201-210.

Goris, J. R., Vaught, B. C., \& Pettit, J. D. (2000). Effects of communication direction on job performance and. Journal of Business Communication, 348-368.

Jumba, V. K. (2016). Relationship between teacher factors and job satisfaction among pre-school teachers in Nyali constituency, Mombasa County . Doctoral dissertation, Kenyatta University. 
Juran, J. M., \& Gryna,, F. M. (1993). Quality planning and analysis: From product development through use. New York: McGraw-Hill.

Kumawu, N. \& Kraws, W. A. (2007) Global Organisation Development: A Model for Africa and the World. Accra: OCIC Ghana Limited

Karia, N., \& Ahmad, Z. A. (2000). Quality practices that pay: empowerment and teamwork. . Malaysian Management Review, 66-76.

Karia, N., \& Asaari, H. A. (2006). The effects of total quality management practices on employees' work-related attitudes. The TQM magazine, 30-43.

Kirkman, B. L., Rosen, B., Gibson, C. B., Tesluk, P. E., \& McPherson,, S. O. (2002). Five challenges to virtual team success: Lessons from Sabre, Inc. Academy of Management Executive, 67-79.

Lau, H. c., \& Idris, M. A. (2001). Research and concepts: The soft foundation of the critical success factors on TQM implementation in Malaysia. The TQM Magazine, 51-60.

Lauture, R., Amewokunu, Y., Sherrie, L., \& Lawson-Body, A. (2012). Impact Of Culture On The

Organisational Commitment Of Public-Sector. International Business \& Economics Research

Journal, 11(3), 331-342

Majeed, S., Mujtaba, H., Saleem, N., Saleem, S., Aziz, T., \& Usman, M. (2012). The Influence of Corporate Culture on Organisational Commitment of Pakistani Banks An Empirical Study. International Journal of Asian Social Science 2, 1370-1377.

Malik, M. E., Nawab, S., Naeem, B., Danish, R. Q. (2010). Job Satisfaction and Organisational Commitment of University Teachers in Public Sector of Pakistan. International Journal of Business \& Management, Vol. 5 (6), p. 17-26.

Martins, N. \& Martins, E. 2003. 'Organisational culture', In Robbins, S.P., Odendaal A. \& Roodt, G. (eds), Organisational Behaviour: Global and Southern African Perspectives. Cape Town: Pearson Education South Africa.

Mba, O. A. (2013). Organisational Culture and Employees Commitment in Bayelsa State Civil Service. Journal of Management Policies and Practices, 35-45.

Meyer, J. P., \& Allen, N. (1996). The Measurement and Antecedents of Affective, Continuance and Normative commitment to the organisation. Journal of Occupational Psychology, 1-18.

Newstorm, J. W., \& Davis, K. (2002). Organisational Behaviour: Human Behaviour at Work. New Delhi Tata Mcgraw: Hill Publishing .

Niacker, N. (2008). Organisational Culture and Employee Commitment; a case study of Nampak Tissue paper mill. Research Gate.

Olu, O. (2009). Impact Assessment of Corporate Culture on Employee Job Performance. Business Intelligence Journal, 388-397.

Poh , J. P. (2001). Total Quality Management (TQM) in Malaysia- A comaparative study on employees perception on managemnt practices in TQM and non TQM companies. . MBA unpubished thesis.

Ramdhani, A., Ramdhani, M. A., \&Ainisyifa, H. (2017). Conceptual Framework of Corporate Culture Influenced on Employees Commitment to Organization. International Business Management, 11(3), 826-803.

Ricardo, J., \& Jolly, J. (1997). Training of teams in the workplace. S.A.M Advanced Management Journal, 4. 
Shoaib, A., Zainab, N., Maqsood, H., \& Sana, R. (2013). Impact of Organisational Culture on Organisational Commitment:A Comparative Study of Public and Private Organisations. Research Journal of Recent Sciences.

Smidts, A., Pruyn, A. H., \& Cees, v. B. (2001). "The impact of employee communication and perceived external prestige on organisational identification. Academy of Management Journal, 1051-1062.

Soltani, E., \& Liao, Y.-Y. (2010). Training interventions: fulfilling managerial ends or proliferating invaluable means for employees? European Business Review, 128 - 152. 